\title{
Daniel Novotný
}

\section{Metafyzika mezi Aristotelem a Analytikou: Zpráva s otaznikem}

„Neochabující houževnatost metafyziky je jedním ze zjevných faktů dějin filosofie. Metafyzika od svého počátku čelila různým útokům a několikrát se již zdálo, že jí byla zasazena rána z milosti“, píše americký filosof a historik Jorge J. E. Gracia ve své knize Metafyzika a její úkol: Hledání kategoriálního základu poznání z r. 1999. ${ }^{i}$ Jak známo, jeden z posledních frontálních útoků proti metafyzice byl veden $\mathrm{v}$ době dospívání analytické filosofie, za vlády novopozitivismu a filosofie prrirozeného jazyka. Útok však kýženého výsledku nedosáhl, došlo $\mathrm{k}$ rozpadu útočné formace. Metafyzika se chopila př́ležitosti, postupně získávala větší a větší podporu, takže v průběhu druhé poloviny dvacátého století můžeme dokonce mluvit o znovuzrození metafyziky $\mathrm{v}$ rámci analytické tradice. V kontinentální tradici dvacátého století probíhal proces přesně opačný. Odmítání metafyziky bylo zpočátku váhavé a

\footnotetext{
i J. J. E. Gracia: Metaphysics and Its Task: The Search for the Categorial Foundation of Knowledge, Albany 1999, str. ix.
} 
nesmělé, postupem času se však radikalizovalo, především s nástupem existencialismu a hermeneutiky, svůj vrchol má v současné dekonstrukci a postmoderně. V této práci chci podat krátkou provizorní zprávu o návratu metafyziky v analytické tradici. (Metafyziku v kontinentální tradici přenechávám povolanějším). ${ }^{\mathrm{i}}$

Nejprve si ale trochu ujasněme významy používaných termínů. Co je to metafyzika? Slovem 'metafyzika' ( $\tau \grave{\alpha} \mu \varepsilon \tau \alpha \grave{\alpha}$

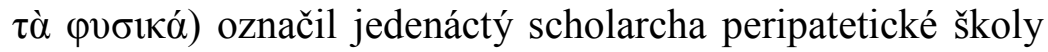
jistý soubor Aristotelových svitků, jež jsou od té doby takto nazývány. Sám Aristoteles tohoto slova neužil, vědeckou disciplínu, kterou se v Metafyzice zabývá, nazývá porůznu jako 'moudrost', 'první filosofie', 'věda o jsoucím jakožto jsoucím', ‘teologie' apod. Aristoteles ovšem nejen že není autorem termínu 'metafyzika', ale dokonce není ani zakladatelem této disciplíny, jak je patrné již z toho, že samotná Metafyzika obsahuje podrobné historické zprávy o badatelských výsledcích Aristotelových předchůdců. S Aristotelem tedy nevznikla metafyzika ani jako slovo ani jako disciplína a proto z ní nelze udělat registrovanou obchodní značku aristoteliků. Aristotelova metafyzika není

\footnotetext{
${ }^{\text {i } V i z ~ n a p r ̌ . ~ k o l e k t i v n i ́ ~ m o n o g r a f i i: ~ P . ~ S o u s e d i ́ k, ~ M . ~ N i t s c h e, ~ M . ~ S ̌ i m s a ~ M . ~(e d s .): ~}$ Návrat metafyziky? Diskuse o metafyzice ve filosofii 20. a 21. století, Praha 2010; jedná se o výstupy českých autorů nejrůznějšího (analytického i kontinentálního) zaměření z konference pořádané v r. 2008, srov. D. D. Novotný: Zpráva z konference Schizma filozofie 20. století. Překonávání metafyziky?, in: Reflexe 35 (2008), str. 137-142; viz také V. Vohánka, D. D. Novotný: Současná křest’anská filozofie v USA a Velké Británii: Dojmy a postřehy, in: Salve 19/2 (2009), str. 5371
} 
pro metafyziky ani normativní ani závazná - v dějinách západní filosofie můžeme pod nálepkou 'metafyzika' najít mnoho různých ne-aristotelských či anti-aristotelských úvah a stanovisek, což samo o sobě není důvod pro jejich diskvalifikaci z metafyzického klubu. Dokonce i v tradici indické a čínské filosofie lze mluvit o metafyzice. ${ }^{i}$ Je zde ovšem problém: pokud návaznost na Aristotela a jeho metafyzický projekt není nutnou podmínkou pro to, aby se něco nazývalo metafyzikou, jak poznáme, co je a co není metafyzikou? Pokud nebudeme mít žádná kritéria legitimního užití slova 'metafyzika', hovory o metafyzice se stanou mlácením prázdné slámy. Pod 'obrodou/koncem metafyziky' si bude Petr představovat zvýšení/snížení čtenářského zájmu o horoskopy a Pavel stavbu/uzavření Velkého hadronového urychlovače. Nějakou, alespoň pracovní, definici metafyziky potřebujeme.

Desítky různých minulých i současných definic metafyziky identifikoval a zhodnotil J. Gracia ve výše zmíněné knize. Některé definice se odvolávají na objekt

\footnotetext{
i Tím nemám na mysli pověry a bláboly theosofistů či vyznavačů feng-šuej, ale původní indické a čínské myšlenkové úsilí, které se v relevantních ohledech (témata, justifikace, metoda) podobá metafyzickému zkoumání západních myslitelů, třebaže samo sebe neoznačuje západním termínem 'metafyzika'. Srov. např. J. Pereira: Hindu Theology: Themes, Texts and Structures, Garden City 1976, P. Williams: Indian Philosophy, in: A. C. Grayling (ed.): Philosophy 2: Further through the Subject, Oxford 1999, str. 793-848, J. Yu, N. Bunnin: 2001, Saving the Phenomena: An Aristotelian Method in Comparative Philosophy, in: B. Mou (ed.): Two Roads to Wisdom? Chinese and Analytic Philosophical Traditions, Chicago 2001, str. 293-312, D. Wong: Comparative Philosophy: Chinese and Western, 2001/2009 [URL = http://plato.stanford.edu/entries/comparphil-chiwes/].
} 
metafyziky (bytí, transcendentálie, kategorie, nejzazší příčiny, substance, Bůh, atd.), některé na její metodu (apriorní/aposteriorní, diskurzivní/intuitivní, induktivní/deduktivní, dialektickou, fenomenologickou, historickou, atd.), některé na její cíl (teoretický, praktický, estetický, kritický, atd.) a konečně některé na typ studovaných propozic (analytické a priori, syntetické a posteriori, syntetické a priori, atd.). Gracia považuje většinu těchto definic za více či méně neadekvátních a nakonec hájí svou vlastní:

„Metafyzika je... [filosofická disciplína], která se snaží (a) identifikovat nejobecnějšś kategorie, (b) definovat nejobecnější kategorie, příp. pokud to není možné, popsat je tak, abychom je mohli identifikovat, (c) určit vztahy mezi nejobecnějšími kategoriemi, (d) zasadit méně obecné kategorie do těch nejobecnějších, (e) určit vztahy méně obecných kategorií $\mathrm{k}$ těm nejobecnějším, včetně těch do kterých nepatř́i. “i

Pro hlubší pochopení by tato definice potřebovala obšírný vysvětlující komentáŕ, řekněme jen toto: Gracia chápe kategorie $\mathrm{v}$ širokém smyslu slova jako cokoli vyjádřeného predikáty, tj. kategorie mohou zahrnovat i to, co

${ }^{\mathrm{i}}$ Gracia: Metaphysics and Its Task, s. 140. 
se tradičně nazývá transcendentálie, navíc se nemusí vzájemně vylučovat, být společně vyčerpávající či neredukovatelné. ' Samo jméno 'metafyzika' pak podle Gracii není prŕiliš vhodné, protože:

„... v dějinách této disciplíny bylo [toto jméno] užito ke zdůrazňování toho, že se tato disciplína zabývá něčím vně tohoto světa, něčím, co není materiální, či že tato disciplína prrichází za studiem fyziky (která se nazývala 'přírodní filosofie'). ... tyto interpretace disciplíny jsou nešt’astné, protože tato disciplína se nezabývá exklusivně jen tím, co je mimo tento svět, či jen tím, co je nemateriální.“،ii

Nicméně vzhledem k tomu, že se jedná o jméno zaběhnuté a tradiční, spojené např. $\mathrm{s}$ Aristotelem či Suarezem, z historických a pragmatických důvodů, ř́ká Gracia, nemá smysl toto jméno odmítat. Metafyzika je tedy podle Gracii:

„... kategoriálním základem všech našich názorů, všeho našeho poznání. Jakožto náhled na naše nejobecnější kategorie a na vztahy méně obecných kategorií k těm

${ }^{\mathrm{i}}$ Gracia: Metaphysics and Its Task, s. 134-137.

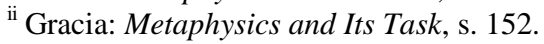


nejobecnějším, je metafyzika pojmový základ všeho dalšího, co víme.“i

Graciova definice metafyziky je široká. Vzhledem $\mathrm{k}$ tomu, že $\mathrm{v}$ jeho neutrálním pojetí mohou být nejobecnější kategorie věcné, pojmové i jazykové, nejrůznější typy antirealistických teorií lze klasifikovat jako metafyziku. ${ }^{\text {ii }}$ Nejen Aristoteles a racionalisté, ale i empiristé a Kant vyhovují Graciově definici. ${ }^{\text {iii }}$ Není proto divu, že metafyzika v tomto smyslu je nevyhnutelná a nezničitelná. Třebaže i extrémní empiristické formy novopozitivismu lze v Graciově širokém smyslu slova interpretovat jako metafyziku, nám samým půjde v této zprávě o posun od silných anti-spekulativních empiristických forem metafyziky $\mathrm{k}$ formám realistickým a spekulativním (= jdoucích za bezprostřední zkušenost). Budeme tedy hovořit o vzestupu realistické a spekulativní metafyziky $\mathrm{v}$ analytické filosofii a $\mathrm{v}$ daném kontextu bude výraz 'anti-metafyzický' znamenat ,anti-spekulativněmetafyzický، iv

\footnotetext{
${ }^{\mathrm{i}}$ Gracia: Metaphysics and Its Task, s. 140.

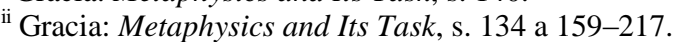

iii Dokonce i David Hume je podle této definice metafyzikem, viz D. D. Novotný: 2006, Is Hume a Metaphysician?: Aristotle vs. Gracia, in: R. Delfino (ed.): What are We to Understand Gracia to Mean? Amsterdam-New York 2006, str. 179192.

iv Svou širokou definici zdůvodňuje Gracia mj. takto: řada autorů zahrnuje do definice metafyziky určité metafyzické pojetí (nominalistické, konceptualistické, realistické), čímž vylučují práci svých kolegů. V samotné definici metafyziky by nemělo být předem dáno to, co má být až výsledkem vlastního metafyzického
} 
Nyní ještě pár slov k adjektivu 'analytický'. Jedná se o označení dominantní anglo-americké filosofické tradice dvacátého století, kontrastované $\mathrm{s}$ tradicí německou, francouzskou, př́p. španělskou, která se označuje jako 'kontinentální'. Oba výrazy, 'analytický' i 'kontinentální', jsou mnohoznačné a vyjadřují řadu vágních pojmů. Analytičtí filosofové nezastávají např. žádnou společnou nauku (nominalismus, naturalismus či logický pozitivismus) a nelze dokonce ani říci, že by všichni použivali stejnou konkrétní metodu, např. formalizaci $\mathrm{v}$ umělém jazyce či analýzu přirozeného jazyka. Analytičtí filosofové se spíše vyznačují jakousi „rodinnou podobnosti““ ve stylu a tématech a v důrazech na trpělivé jazykové a pojmové vyjasňování problémů, rozvoj technické terminologie, snahu o co nejvyšší preciznost a př́sné argumentační standardy. V historickogenetickém smyslu lze říci, že analytičtí filosofové jsou ti, kteř́ se naučili filosofovat u G. Fregea, B. Russella, G. E. Moorea, L. Wittgensteina či u jejich žáků a žáků jejich žáků.

Nuže přejděme konečně $\mathrm{k}$ historii a současnosti (spekulativní) metafyziky v analytické tradici. Samotná raná

zkoumání. Realistickou definici metafyziky/ontologie uvádí z analytických autorů např. E. Runggaldier: „ontologie je... filosofická disciplína, které jde o to, co je, a která poskytuje informace o esenci (Wesen) a přirozenosti (Natur) všeho. ... Kromě výkazu a charakteristiky fundamentálních známek skutečnosti je na ontologii také kladen požadavek prozkoumat základní „díly“ skutečnosti a to, jak do sebe „zapadají“ (E. Runggaldier, Ch. Kanzian: Grundprobleme der Analytischen Ontologie, Paderborn 1998, s. 14). Pro obhajobu tohoto prrístupu srov. M. J. Loux: Metaphysics: a contemporary introduction, London 1998 (2002²), s. 1-19 a 250-292. 
analytická filosofie nebyla nijak anti-metafyzicky zaměřená. Fregeovy názory na základy logiky a matematiky nelze považovat za anti-metafyzické a jak Russell, tak Moore brali vážně tradiční metafyzické problémy a hledali jejich pozitivní řešení. Raná analytická filosofie se nevymezovala proti metafyzice jako takové, ale proti idealistické a monistické metafyzice F. H. Bradleyho (1846-1924) a jiných tehdy vlivných britských autorů. Kromě obnovy realismu byla výrazným rysem rané analytické filosofie důvěra v možnosti logického řešení filosofických problémů a nadšení z nových objevů $v$ matematice a logice.

Boj proti (spekulativní) metafyzice začal $\mathrm{v}$ analytické filosofii až s nástupem novopozitivismu (M. Schlick, A. J. Ayer, R. Carnap) a filosofie přirozeného jazyka (G. Ryle, J. L. Austin, L. Wittgenstein) ve dvacátých, třicátých a čtyřicátých letech. Třebaže i v tomto období působila řada analytických metafyziků (mezi něž lze počítat i samotného Russella), jejich vliv byl poměrně malý. V padesátých a šedesátých letech anti-metafyzické nadšení analytiků počalo klesat. Zásluhu na znovuzrození metafyziky mají především Willard van Orman Quine (1908-2000) v USA a Peter Strawson (1919-2006) ve Velké Británii. ${ }^{i}$ Po nesmělém začátku se analytičtí autoři začali postupně zabývat řadou témat známých z tradiční metafyziky: obecniny, modality,

\footnotetext{
${ }^{\mathrm{i}}$ Viz např. D. Zimmermann: Metaphysics after the Twentieth Century, in: Oxford studies in metaphysics 1, Oxford 2004, str. IX-XII.
} 
propozice, čísla, prríčinnost, svoboda, psychofyzický dualismus, argumenty boží existence, atd. Nová analytická metafyzika vznikla většinou nezávisle na metafyzice starověké a středověké a nabyla proto nejrůznějších podob, pro historika filosofie často velmi překvapivých. ${ }^{\mathrm{i}}$

Domnívám se, že zjednodušeně vzato můžeme rozlišit trojí typ současné analytické metafyziky: postpozitivistický, neoklasický a neoaristotelský. První typ je prímou metamorfózou anti-metafyzických úvah $\mathrm{z}$ adolescentního období analytické filosofie. Metafyzika je v tomto pojetí poměrně „slabá““ (,vyfouknutá“, deflationary), je to jen jakási nadstavba prŕrodních věd. Za hlavního představitele postpozitivistické metafyziky lze považovat Quinea. Druhý typ analytické metafyziky nazývám neoklasický, protože metafyzika v tomto pojetí je obsažnější a netriviálnější, nejedná se již o pouhou logickou analýzu nejnovějších učebnic fyziky a psychologie. Tento typ metafyziky ovšem nelze snadno charakterizovat co do obsahu či metodiky, jeho představitelé zastávají nejrůznější stanoviska na nejrůznější otázky. Jedná se o heterogenní směs názorů a argumentů, které přes svou diverzitu ukazují na metafyziku jakožto svébytnou disciplínu a tím se vymezují od prvního typu. Za jednoho z hlavních průkopníků neoklasické metafyziky lze

\footnotetext{
${ }^{\mathrm{i}}$ Uved'me jako př́klad fakt, že řada analytických metafyziků nepovažuje Boha za centrální předmět své disciplíny. $Z$ velkého sociologického průzkumu (URL=<http://philpapers.org/surveys/>) vyplývá, že většina současných AngloAmerických metafyziků se kloní k ateismu (64.5\%; spíše k teismus se kloní pouhých $22.2 \%$ ).
} 
považovat Strawsona. Konečně zde máme třetí typ metafyziky, neoaristotelský. Představitelé tohoto směru se vyznačují větší či menší blízkostí stanoviskům aristotelské tradice. Tento směr začíná být explicitně reflektován jakožto směr až v nedávných letech, třebaže zpětně lze považovat řadu děl a autorů za představitele neoaristotelské analytické metafyziky. Není snadné určit nějakého hlavního průkopníka tohoto směru (v jistém smyslu je to opět Strawson), některé z představitelů si uvedeme níže.

Podívejme se nyní v krátkosti na zrod postpozitivistické metafyziky. Jak známo, novopozitivismus neboli logický pozitivismus vedl razantní kampaň proti sebemenšímu náznaku metafyziky. Obdivuhodně čistě shrnul novopozitivistické argumenty proti metafyzice Rudolf Carnap (1891-1970) v eseji „Překonání metafyziky skrze logickou analýzu jazyka“ (1931). Carnap argumentuje takto: Cílem logiky je vyjasnění smyslu vět, v nichž jsou vyjádřeny vědecké poznatky. Zatímco u empirických vět vede proces vyjasňování $\mathrm{k}$ úspěchu, věty metafyzické (jakožto věty domnělé vědy) jsou beznadějně nesmyslné, jsou to pouze

\footnotetext{
${ }^{i}$ Mé dělení se liší od dělení současných směrů analytické metafyziky navrhnuté Runggaldierem/Kanzianem, Grundprobleme. Runggaldier/Kanzian rozlišují směry naturalistické (Quine \& co), fenomenologické (R. Chisholm, P. Simons, B. Smith, K. Mulligan) a deskriptivní (P. Strawson). Směr naturalistický nazývám 'postpozitivistický' a myslitele fenomenologické a deskriptivní řadím dohromady do proudu neoklasického, protože se jedná spíše o individuální myslitele než o „směry“. Runggaldier/Kanzian nevěnují ve své knize dostatečnou pozornost myslitelům neoaristotelským, třebaže je samotné lze řadit do této skupiny.
} 
„Zdánlivé věty“ (Scheinsätze; pseudo-statemements). Tyto věty jsou nesmyslné ze dvou důvodů:

(1) Za prvé se v nich vyskytují bezesmyslné výrazy jako 'princip' či ‘Bůh'. Zatímco u řádných výrazů jako 'prší' můžeme v rámci jejich výskytu ve větě nalézt možnost verifikace této věty (její pravdivostní podmínky), u metafyzických výrazi̊, zkušenostně neověritelných, to nejde.

(2) Za druhé podle Carnapa porušují metafyzické věty logickou syntax, tj. nejsou správně utvořeny. Věta 'nic nicuje' je podobně nesmyslná jako 'Caesar je a' či 'Caesar je prvočíslo' (tyto věty nejsou ani pravdivé, ani nepravdivé, ale bezesmyslné, protože lidé a čísla jsou různé typy objektů). ${ }^{\mathrm{i}}$

„Proč se tolik úctyhodných myslitelů všech dob“, ptá se Carnap, „zabývalo metafyzikou, jde-li o pouhá nesmyslná slova, nesmyslně kladená vedle sebe?“ Odpověd’: metafyzika

\footnotetext{
${ }^{\mathrm{i}} \mathrm{R}$. Carnap: The Elimination of Metaphysics through the Logical Analysis of Language, in: A. J. Ayer (ed.): Logical Positivism, New York 1959, str. 60-81 (1. vydání 1931). Carnap se ve svém článku výslovně obrací především proti metafyzickým výrokům vzatým z Heideggerova spisu Co je metafyzika? (1929). Jeho útok je ovšem veden proti veškeré metafyzice a dokonce i proti etice a estetice. Charakteristiku toho, co myslí metafyzikou, připojil Carnap až k anglickému překladu svého článku z r. 1959: „domnělé poznání esencí věcí, které přesahuje oblast induktivních věd, tj. toho, co je empiricky založeno“. Kromě Heideggera, jmenuje Carnap jako metafyziky Fichteho, Schellinga, Hegela a Bergsona, nezmiňuje kupodivu Platóna ani Aristotela.
} 
sice nemá teoretický obsah, jistý obsah však přeci jen má. Jedná se o „vyjádření obecného postoje nějaké osoby vůči životu“. Tento postoj je od nepaměti vyjadřován $\mathrm{v}$ mytologiích, kde má svůj původ poezie, teologie - a metafyzika. Na rozdíl od poezie je ale metafyzika neadekvátním vyjádřením postoje $\mathrm{k}$ životu. Metafyzikové totiž nevědí, co dělají a v tom se liší od umělců, kteří alespoň vědí, co dělají. Metafyzikové si myslí, že dělají vědu a přitom to, co dělají, nemá $\mathrm{s}$ vědou vůbec nic společného. Metafyzické spory jsou pak absurdní tak jako spory básně $\mathrm{s}$ básní. Carnap uzavírá svou stat' úvahou o hudbě:

„Hudba je asi nejčistším způsobem jak vyjádřit životní postoj, nebot' je osvobozená od jakéhokoli zaměření na nějaký objekt. Pocit či postoj harmonie, který se metafyzik snaži vyjádřit $\mathrm{v}$ monistickém systému, je mnohem jasněji vyjádřen v Mozartově hudbě. A když se metafyzik snaží verbalizovat dualisticko-heroický postoj $\mathrm{k}$ životu $\mathrm{v}$ dualistickém systému, není to snad tím, že nemá Beethovenovu schopnost vyjádřit tento postoj přiměřenějším způsobem? Metafyzikové jsou hudebníci bez hudebního nadání. [Metafyzikové]... Místo aby aktivovali svi̊j sklon [pracovat s pojmy a myšlenkami] ve vědě a uspokojili svou potřebu vyjádření [životního postoje] v umění, obojí směšují a produkují strukturu, 
která nepřináší nic pro poznání a nestačí ani na adekvátní vyjádření životního postoje.

Naše domněnka, že metafyzika je nedostatečnou náhražkou za umění... je dále potvrzena tím, že metafyzik, který byl patrně $\mathrm{v}$ nejvyšší míře obdařen uměleckým talentem, totiž Nietzsche, se téměř vždy vyhýbal omylu obojí směšovat. Velká část jeho díla má empirický obsah... Nicméně v díle, kde nejsilněji vyjádřil to, co ostatní vyjadřují pomocí metafyziky nebo etiky, totiž v Tak pravil Zarathuštra, Nietzsche nezvolil zavádějící teoretickou formu, ale formu otevřeně uměleckou, poetickou. ${ }^{\text {‘i }}$

Je zajímavé, že Carnap $\mathrm{v}$ podstatě souhlasí se stanoviskem Martina Heideggera (1889-1976), třebaže by se na první pohled zdálo, že se tito myslitelé nemohou shodnout naprosto v ničem (rozhodně to něco, na čem se nejvíce neshodli, bylo 'Nic'). Heidegger píše:

„Tím je v základech prokázána výše uvedená teze: Nic je původem záporu, nikoli naopak. Je-li takto zlomena moc rozumu na poli tázání po ničem a po bytí, pak je tím také

${ }^{\mathrm{i}}$ Carnap: The Elimination of Metaphysics, s. 80. 
rozhodnut osud vlády „logiky“ ve filosofii. Idea „logiky“ se sama rozkládá ve víru původnějšího tázání.“i

Můžeme si povšimnout, že jak Heidegger, tak Carnap dochází ke stejnému závěru, totiž že metafyzická témata nejsou př́stupná logickému myšlení. Není-li možná metafyzika ve smyslu „logického př́stupu k metafyzickým tématům“, je třeba si zvolit mezi logikou či metafyzickými tématy. Carnap a analytická tradice si volí logiku, Heidegger a kontinentální tradice si volí (alespoň zpočátku) metafyzická témata. ${ }^{\text {ii }}$

Carnap sám si postupem času uvědomil, že v některé otázky a tvrzení, např. ty, které se týkají existence nějakého typu entit, nejsou ani zcela „hudební“ (tj. bezesmyslné) a ani

\footnotetext{
${ }^{\text {i }}$ M. Heidegger: Co je to metafyzika?, Praha 1993 (1. vydání 1929), s. 57.

ii Podrobněji se tímto sporem zabývá P. Sousedík: Carnapưv pokus o kritiku Heideggerovy metafyziky: Dva protipóly evropské filosofie 20. stoletî", in: M. Nitsche, P. Sousedík, M. Šimsa, M. (eds.): Schizma filosofie 20. století, Praha 2005, str. 195-216. Sousedík taktéž dochází k závěru, že základním bodem sporu je logika: „Carnap hází přes palubu Heideggerovu metafyziku, protože odporuje jeho logice, Heidegger zase hledí se značným despektem na celou logiku, protož neumožňuje jeho myslivější myšlení.“"(s. 216). Sousedík hájí Heideggera proti Carnapovi, nebot' „i přesto, že Heideggerovy či [jiné] mystické texty nemají odpovídající logickou strukturu, není... vyloučeno, že se v nich skrývá velmi cenné poznání“(s. 210). To je sice pravda, ale jakékoli cenné poznání lze jistě vyjádřit odpovídající logickou strukturou. Potíž není podle mého názoru v Carnapově důrazu na logiku, ale v jeho neadekvátním pochopení podstaty logiky. (Pro vynikající návrh alternativního pojetí logiky, viz L. Novák: Sofiina volba pokantovské filosofie aneb chvála nástroje, in: Sousedík, P., Nitsche, M., Šimsa, M. (eds.), Návrat metafyziky? Diskuse o metafyzice ve filosofii 20. a 21. století, Praha 2010, str. 287-310).
} 
striktně logicko-empirické. ${ }^{i}$ Další „Změkčeni“ antimetafyzického postoje ovšem přichází až s Carnapovým žákem Quinem. U Quinea se do popředí dostaly otázky, které Carnap odsunul jako „externí“. V článku „Dvě dogmata empirismu“ z r. 1951 podrobuje Quine kritice dva předpoklady tehdejšího empiricismu:

„Moderní empiricismus je do velké míry podmíněn dvěma dogmaty. Proním z nich je názor, že je nějaká fundamentální propast mezi pravdami analytickými, které jsou založeny ve významech (meanings) nezávisle na faktech, a pravdami syntetickými, které jsou založené na faktech. Druhým dogmatem je redukcionismus: názor, že každý smysluplný oýrok je ekvivalentní nějakému logickému konstruktu z termínů, které referují k př́mé zkušenosti.“ii

Pro nás je momentálně důležitý Quineův názor, že veškerá ontologie (= názor na to, co je) vyplývá z našeho

\footnotetext{
${ }^{\mathrm{i}}$ Carnap např. začal rozlišovat mezi interními a externími otázkami. Interní otázky jsou ty, které se týkají existence entit v rámci nějakého daného pojmového rámce; tyto otázky jsou teoreticky rozhodnutelné (at' už logicky či empiricky). Externí otázky jsou ty, které se týkají samotné volby pojmového rámce; tyto otázky jsou podle Carnapa řešitelné pouze pragmaticky, pomocí kritérií jako jsou explikační síla či jednoduchost. Vezměme např. otázku 'Existují věci?' Tato otázka je dle Carnapa externí a odpověd' na ní spočívá v přijetí či odmítnutí pojmového rámce s termínem 'věc', tj. určitého způsobu mluvení. Pokud ale jazyk s termínem 'věc' přijmeme, otázka, zda nějaké $x$ je věcí, se stává otázkou interní (empirickou). ${ }^{\text {ii }}$ W. v. O. Quine: From a Logical Point of View: Nine Logico-Philosophical Essays, Second Revised Edition, Cambridge, MA 1980, s. 20.
} 
pojmového schématu, jehož volba je daná nikoli realitou, ale rovnováhou mnoha, především pragmatických, faktorů (jednoduchost, explikační síla, atd.). Quine je sice př́telem prrírodních věd, které podle něj hrají zásadní roli ve volbě pojmového schématu, ale mezi př́rodní vědou a mytologií neexistuje podle něj zásadní předěl:

"Jako empirista nadále považuji pojmové schéma vědy za nástroj, který vposled slouží $k$ předpovídání budoucích zkušeností ve světle minulých zkušeností. Fyzické objekty jsou pojmově včleňovány do situace jako vhodní prostředníci-nikoli ve soých empiricky založených definicích, ale jednoduše jako neredukovatelné postuláty (posits), které jsou epistemologicky vzato srovnatelné $s$ homérovskými bohy. Jako laický fyzik věřím ve fyzikální objekty a ne v Homérské bohy; považuji za vědecký omyl zastávat opačný názor. Nicméně z hlediska epistemologických podkladů se fyzické objekty a bohové liší pouze co do stupně a nikoli co do druhu. Obojí typ entit vstupuje do našich koncepcí pouze jako 
kulturní

„postulát"

$(\text { posit })^{\lambda \mathrm{i}}$

Quineovo stanovisko lze charakterizovat jako naturalismus (= setření rozdílu mezi metafyzikou a prírodní vědou), pragmatismus (= pojmová schémata, tj. naše ontologie, jsou pouhou volbou vhodného instrumentu $\mathrm{k}$ pochopení „proudu naší zkušenosti“") a holismus (= nelze verifikovat či falsifikovat jednotlivá přesvědčení, ale jen jejich „celkovou sít“"). Jedná se o jakousi směs metafyziky/empiricismu. Směs, kde nelze rozlišit, co z naší teorie pochází ze zkušenosti a co je dáno pragmatickou volbou jazyka s jeho ontologickými závazky.

Ke Quineovi a jeho následovníkům bychom ještě mohli říci mnohé, necht' nám však postačí výše řečené jako ilustrace jakéhosi typu metafyziky, jejíž možnost Quine svou „empiristickou sebe-kritikou“ otevřel. Přejděme nyní k druhému typu metafyziky.

Neoklasický typ analytické metafyziky se prosazuje především s dílem P. Strawsona. ${ }^{\text {ii }}$ Strawsonovým zájmem je popsat svět nikoli tak jak je, ale jak o něm myslíme $a$ mluvíme. Jeho metafyzika je tedy zřetelně novokantovským

\footnotetext{
${ }^{\mathrm{i}}$ Quine: From a Logical Point of View, s. 44.

ii Dalším kandidátem na post otce neoklasické analytické metafyziky je Roderick Chisholm (1916-1999) se svými významnými pracemi o intencionalitě, nutných a kontingentních entitách, závislých a nezávislých entitách, atd. Chisholm je na rozdíl od Strawsona explicitním metafyzickým realistou, jeho metodologie čerpá $\mathrm{z}$ rané realistické fenomenologie a lze ji považovat za ,,analytickou fenomenologii“".
} 
projektem, třebaže se ve svém provedení nakonec mnohem více podobá metafyzice Aristotelově než Kantově. Strawson rozlišuje mezi metafyzikou deskriptivní a revizionistickou, přičemž sám se hlásí k metafyzice deskriptivní:

„Metafyzika byla často revizionistická a méně často deskriptivní. Deskriptivní metafyzika se spokojí s popisem aktuální struktury našeho myšlení o světě, revizionistická metafyzika se stará o to, aby vytvořila lepší strukturu.... Žádný skutečný metafyzik asi nebyl, co do intence či výsledku, zcela jedním či druhým. Můžeme ale zhruba určit: Descartes, Leibniz, Berkeley jsou revizionisté, Aristoteles a Kant deskriptivisté. “ii

Svůj projekt deskriptivní metafyziky počíná Strawson analýzou fenoménu identifikace jednotliviny. Jaké jsou podmínky toho, že když někdo mluví o nějaké jednotlivině, já či někdo další mu rozumí? Základním lingvistickým prostředkem, který slouží kidentifikaci, jsou ukazovací výrazy, které lze použít $\mathrm{v}$ př́ípadech, kdy jak mluvčí, tak posluchač aktuálně vnímá danou jednotlivinu. Dalšími prostředky jsou jména a popisy (deskripce), které lze použít i v prrípadech, kdy mluvčí či posluchač jednotlivinu nevnímá. V obou př́padech ovšem odvozujeme identifikaci jednotlivin

\footnotetext{
${ }^{\mathrm{i}}$ P. Strawson: Individuals: An Essay in Descriptive Metaphysics, London 1990 (1. (1. vydání1959), s. 9.
} 
od základních ukazovacích identifikací a ty se vposled opírají o systém časo-prostorových relací.

Jsou mezi jednotlivinami některé základní jednotliviny (identifikovatelné prímo $\mathrm{v}$ časo-prostoru) a jiné odvozené (identifikovatelné nepř́mo, např̀. události)? Strawson hájí stanovisko, že ano: materiální věci jsou základními jednotlivinami, protože jen ony se hodí $\mathrm{k}$ „výstavbě“ časo-prostorového systému, jen ony jsou „trvající a místo-zaujímající“. Typickou závislou (odvozenou) kategorí jednotlivin jsou pak ,soukromé zkušenosti“ (bolest zubů, vjem červeně, atd.), ,teoretické konstrukty“, procesy a události. Tyto odvozené jednotliviny jsou totiž identifikovatelné jen díky materiálním věcem.

Mezi materiálními věcmi se vyskytují takové, kterým připisujeme nejen fyzikální vlastnosti (umístění a pozici), ale i mentální vlastnosti (jednání, intence, vjemy, myšlenky, pocity, vnímání, pamět'). Jak vysvětlit tuto zvláštnost, tj. že se zdá, jakoby se dva zcela odlišné typy vlastností připisovali stejné jednotlivině? Podle Strawsona jsou tři možné odpovědi:

(1) tyto typy vlastností se ve skutečnosti připisují dvěma odlišným věcem (Descartes: res extensa, res cogitans)

(2) mentální vlastnosti se ve skutečnosti ničemu nepřipisují (Hume, možná Wittgenstein); 
(3) materiální věci s myslí jsou osoby ve smyslu neredukovatelné, základní kategorie našeho pojmového schématu.

Strawson hájí třetí teorii, protože jak první, tak druhá teorie jsou podle něho iracionální (pokud by byly pravdivé, nemohli bychom je zastávat).

I zde by bylo možné pokračovat ve výkladu, důležitá pro nás je ovšem jen základní orientace $\mathrm{v}$ tom, co lze nazvat „neoklasickou metafyzikou“: jedná se o metafyziku zřetelně bližší tomu, co metafyzikou rozuměli starověcí a středověcí autoři. Mezi „neoklasické autory“ by bylo možné zařadit řadu prominentních analytických autorů, jako jsou např. David Armstrong (n. 1926), Saul Kripke (n. 1940), David Lewis (1941-2001) či Peter van Inwagen (n. 1942). Celkově vzato se oproti metafyzice postpozitivistické vyznačuje neoklasická analytická metafyzika mnohem větší systematičností a důvěrou $\mathrm{v}$ možnosti rozumu proniknout $\mathrm{k}$ základům reality. Jak jsem již řekl, jedná se o skupinu velmi rozmanitou, čítající i antirealisty, pričemž přechod mezi postpozitivistickou a neoklasickou metafyzikou je poměrně vágní. $^{\mathrm{i}}$

\footnotetext{
i Významné příspěvky k neoklasické metafyzice, byt' tyto autory pravděpodobně není možné zařadit do „neoklasické“ skupiny, podali např. Hilary Putnam (n. 1926) a Nicholas Rescher (b. 1928). Van Iwagen se hlásí k postpozitivistické metafyzice Quineova typu (především s ohledem na metodologii), třebaže celkový obsah Quineovy a van Inwagenovy metafyziky je velmi odlišný, viz D. Chalmers, D. Manley, R. Wasserman (eds.): Metametaphysics: New Essays on the Foundations of Ontology, New York 2009.
} 
Nyní se již chýlíme k závěru této zprávy. Rád bych v ní zmínil metafyziku neoaristotelskou. Za neoaristotelské považuji řadu současných myslitelů, kteří se ve svých pracích sbližují se stanovisky aristotelské tradice a to někdy zcela nezávisle na historické tradici. Jádrem aristotelského pojetí metafyziky je přssvědčení, že se jedná o první vědu, zabývající se nejhlubšími základy bytí/reality, např. pojmy jako jsou substance, kvantita, kvalita, vztah, duše, vůle, potence, jsoucno, atd. a principy jako jsou např. princip sporu či dostatečného důvodu. Jedná se pojmy a principy, které vstupují do veškeré vědy a lidského poznání a nelze říci, že by např. současná teoretická fyzika či biochemie měla privilegovaný př́istup k poznávání těchto základních pojmů a principů. Zmiňme ještě některá stanoviska, která lze považovat za charakteristicky neoaristotelská:

- netriviálnost existence a existenční pluralita;

- $\quad$ aktualita a potencialita bytí (a aplikace napřr. $\mathrm{v}$ hylemorfismu)

- „čtyř-kategoriální ontologie“ (tj. rozlišení obecných a jednotlivých substancí a akcidentů);

- $\quad$ esencialismus a de re nutnost;

- $\quad$ kauzalita věcí nikoli událostí;

- anti-redukcionismus běžných individuí (především osob) ${ }^{\mathrm{i}}$

\footnotetext{
${ }^{\mathrm{i}}$ Nejlepší vyjádření základních neoaristotelských principů lze nalézt zde: A. J. Freddoso: Suarez on Metaphysical Inquiry, Efficient Causality, and Divine
} 
Za významné představitele neoaristotelské metafyziky považuji mj. následující autory: Elisabeth Anscombe, William Lane Craig, Edward Feser, Kit Fine, James Franklin, Alfred J. Freddoso, Peter Geach, John Haldane, Joshua Hoffman, Ingvar Johansson, Anthony Kenny, Robert Koons, Gyula Klima, Brian Leftow, Michael J. Loux, E. J. Lowe, Uwe Meixner, Barry Miller, David S. Oderberg, Alexander Pruss, Michae Rae, Gary Rosenkrantz, Edmund Runggaldier, Peter Simons, Stanislav Sousedík, Eleonore Stump, William F. Vallicela a David Wiggins. ${ }^{i}$ Někteří z těchto autorů jsou aristotelskou tradicí př́mo inspirováni (publikovali např. na poli dějin filosofie), jiní $\mathrm{k}$ aristotelským stanoviskům dospívají svým vlastním způsobem, nezávisle na tradici. Neoaristotelská analytická metafyzika samozřejmě vykazuje i řadu rozdílů od tradiční aristotelské metafyziky (např. $\mathrm{v}$ metodologii či $\mathrm{v}$ disciplinárním přerozdělení filosofie řada témat tradiční logiky a prírodní filosofie je považována nyní za součást metafyziky).

Je otázkou nakolik je neoaristotelská tradice životaschopná a zda uhájí své místo pod filosofickým Sluncem. Stojí před ní řada výzev, např. integrace dědictví post-středověké filosofie, integrace fundamentálních

Action, in: Francisco Suárez, On Creation, Conservation, and Concurrence:

Metaphysical Disputations 20-22, translation, notes, and introduction by Alfred J. Freddoso, South Bend 2002, str. xi-cxxiii, S. Sousedík: Identitní teorie predikace, Praha 2006.

i Jedná se o „rodinnou podobnost“, netvrdím, že by všichni jmenovaní autoři zastávali všechna jmenovaná stanoviska a explicitně se hlásili k neoaristotelismu. 


\section{AlOHI III.5}

elementů $\mathrm{z}$ vědy a filosofie vědy (fyziky, biologie, informatiky, matematiky, psychologie, sociologie), integrace induktivní metodologie a probabilistických teorií, integrace současné analytické filosofie náboženství, atd. Sociologicky vzato je neoaristotelská metafyzika jen malou částí současné analytické metafyziky, která je jen (poměrně) malou částí současné analytické filosofie, která je jen malou částí současné profesionální filosofie, která je jen malou částí současného lidského myšlení o nejhlubších otázkách života. Měli bychom se nicméně vážně a kriticky zamyslet: Proč metafyzika, obzvláště ve své neoaristotelské podobě, znovu a znovu povstává k životu? Jedná se o projev trvalé tendence lidského ducha proniknout k pravdě? Či naopak neschopnosti osvobodit se jednou provždy od iluzí?

Tato zpráva byla podpořena grantem GAČR (P401/11/P020). 